\section{Alvorlig svikt i redaktørens dømmekraft}

Stor ble min forskrekkelse da jeg leste innlegget til gjesteskribenten i Tidsskriftet nr. 18/2010, Hans-Erik Dyvik Husby, av de fleste bedre kjent som Hank von Helvete i Turboneger (1). Her

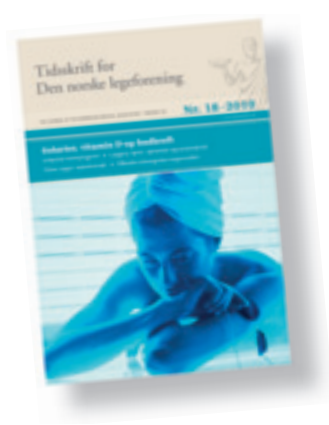
fremsto han som «kommisjonær i Citizens Commission on Human Rights», en organisasjon grunnlagt av Scientologikirken. Han benytter spalteplassen til et ekstremt usaklig og aggressivt angrep på psykiatrien, som han karakteriserer som «gjøkungen i medisinen», som må kastes ut. Han påstår at psykiatrien har fått sterk innflytelse på fastlegenes virksomhet, og at psykiatrien ikke dreier seg om vitenskapelig basert virksomhet for å hjelpe mennesker, men om en konspirasjon mellom psykiatere og legemiddelindustrien med eneste formål å selge legemidler (!), og benytte fastlegene som redskaper for dette. Han fortsetter med å benytte påstander man kjenner igjen fra 1960-årenes «anti-psykiatri», om at diagnosene i psykiatrien er «funnet opp» (for å selge legemidler), og ikke har noe vitenskapelig grunnlag, og at «psykiatriske forstyrrelser ikke er reelle sykdommer som krever medisinsk behandling». Etter min mening har han ikke forstått noe av hva medisinsk diagnostikk og behandling er, det være seg i somatikken eller i psykiatrien.

Jeg skal ikke gå inn i noen diskusjon med gjestespaltisten, til det er hans innlegg for usaklig og dårlig fundert. Mitt anliggende er å rette kritikk mot redaktøren som har sluppet til dette, det viser en alvorlig svikt i dømmekraft.

Jeg antar at man blir invitert av redaktøren til å komme med et innlegg som gjestespaltist, eller om man selv sender inn et innlegg, så blir dette lest i gjennom for å sjekke om det er et innlegg som kan være viktig og interessant for leger. Hva var grunnlaget for å invitere Dyvik Husby? Finnes det noe $\mathrm{i}$ hans karriere som artist og ev. samfunnsdebattant som tilsier at han har noe viktig å si til allmennheten og til legene? Det tror jeg knapt, og hans innlegg viser i hvert fall at det ikke er tilfelle. For øvrig burde hans tilknytning til Scientologikirken være nok til at redaktøren skulle vært ekstremt skeptisk. Denne organisasjonen rekrutterer medlemmer gjennom å tilby en personlighetstest, som alltid viser at man har betydelige problemer, men at Scientologikirken kan hjelpe med sine (dyre) kurs. Det er allment kjent at datteren til en av våre kolleger tok en slik test like i forkant av sitt selvmord.

Nå skal selvfølgelig takhøyden være stor i vårt tidsskrift, og vi skal være åpne for å utsette oss for kritikk fra allmenheten og fra deltakere i samfunnsdebatten, men dette innlegget bidrar ikke på noen måte til en refleksjon over vår virksomhet. Redaktøren har kastet bort verdifull spalteplass, og gitt en talerstol til en person og en organisasjon som ikke fortjener å bli tatt alvorlig.

\section{Vidje Hansen}

Psykiatrisk forskningsgruppe

Universitetet i Troms $\varnothing$

\section{Litteratur \\ 1. Husby H-ED. Gjøkungen i medisinen. Tidsskr Nor Legeforen 2010; 130: 1892}

\section{Feilinformert om influensaserologi}

I kommentarspalten i Tidsskriftet nr. 19/2010 skriver Scheel og medarbeidere at de i september 2009 ble gjort oppmerksom på at ingen laboratorier i Norge utførte influensaserologi (antistoffpåvisning), kun antigenpåvisning (1).

Her er forfatterne feilinformert. I det registeret som kalles Metodekatalogen og som forvaltes av Folkehelseinstituttet, kan man finne alle analyser som i dag utføres i virologi/serologi ved de medisinsk-mikrobiologiske laboratoriene i Norge. Alle laboratoriene, og derfor også Scheel m.fl., har adgang til dette registeret.

Registeret viser at det er ti laboratorier som i dag tilbyr influensaserologi som en del av sin rutine. Antallet var høyere før, men under pandemien i 2009 ble det rapportert om influensa A- og influensa B-virusinfeksjon påvist ved antistoffundersøkelser fra følgende sju laboratorier: Akershus, Bergen, Bodø, Drammen, Molde, Stavanger og Tønsberg. Store deler av landet var ut fra dette, i alle fall i perioder, dekket med serologisk diagnostikk av influensa.

Det påvises antistoffer som i reaksjon med typespesifikt antigen (nukleoprotein og matriksprotein) i viruset binder komplement, komplementbindingsreaksjonen. Diagnosen stilles ved signifikant titerstigning $(4 x)$, i serumprøver tatt to ganger med ca. en ukes avstand, eller ved høyt titer i enkeltprøve når de kliniske funnene er typisk. De typespesifikke antigenene er så stabile både for Influensa A og influensa $\mathrm{B}$ at reaksjonen kan benyttes både ved sesonginfluensa og når det kommer en ny pandemisk stamme, uavhengig av eventuelle antigene forandringer i hemagglutininet (HA) eller nevraminidasen $(\mathrm{N})$.

$\mathrm{Vi}$ oppfordrer de laboratoriene som fortsatt har et tilbud om influensakomplementbindingsreaksjon til å opprettholde dette. Det er viktig at noen fortsetter med slik serologisk diagnostikk fordi det kan være viktig hos enkelte pasienter å kunne få påvist influensa med en alternativ metode til polymerasekjedereaksjonstest (PCR), spesielt $i$ tilfeller der man er for sent i forløpet til å kunne påvise agens. Dette vil også gi oss et mer korrekt bilde av utbredelse og omfang av epidemien/pandemien.

Subtypespesifikk serologi (antistoffmåling mot hemagglutinin) for influensa A har til nå kun vært gjort i forskningsprosjekter og som del av overvåkingen ved det nasjonale influensalaboratoriet ved Nasjonalt folkehelseinstitutt (2) og ved Gades institutt, Universitetet i Bergen, først og fremst i forskningssammenheng, f.eks. Pandemrix vaksinestudie hos sykehusansatte i 2009 (Gro Njølstad, personlig meddelelse). Det var ikke naturlig å tilby denne typen analyse som pasientrettet diagnostikk, også fordi det var usikkert om resultatet kunne brukes til å bedømme beskyttende immunitet.

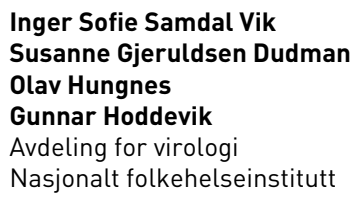

